\title{
Characterization of Staphylococcus spp. strains in milk from buffaloes with mastitis in Brazil: the need to identify to species level to avoid misidentification
}

\author{
[Caracterização de cepas de Staphylococcus spp. isoladas de leite de búfalas com mastites em \\ Brasil: a necessidade de se identificar até nível de espécie para evitar erros de identificação] \\ V. Coimbra-e-Souza ${ }^{1}$, M.A.V.P. Brito ${ }^{2}$, R.C. Chamon $^{1}$, M.S. Laport ${ }^{1}$, M. Giambiagi-deMarval ${ }^{1 *}$ \\ ${ }^{1}$ Instituto de Microbiologia Paulo de Góes - Universidade Federal do Rio de Janeiro - Rio de Janeiro, RJ \\ ${ }^{2}$ Embrapa Gado do Leite - Juiz de Fora, MG
}

\begin{abstract}
Mastitis is an inflammation of the mammary gland that affects dairy cattle worldwide causing economic losses. Coagulase-negative staphylococci (CNS) are the predominant cause of this type of infection. We have recently showed that coagulase-positive staphylococci could be misidentified. So, the aim of this study was to characterize the Staphylococcus spp. strains initially classified as coagulase-negative Staphylococci, isolated from buffalo with subclinical mastitis. Milk of buffaloes with mastitis in herds was collected and 9 strains were identified as CNS by phenotypic tests. Molecular methodologies latter identified the strains as coagulase-negative Staphylococcus chromogenes (5), coagulase-positive Staphylococcus hyicus (2) and coagulase-positive Staphylococcus aureus (2). Our results strongly support the need to identify the isolates to a species level in order to avoid misidentification and to be aware of the classification using the coagulase test alone.
\end{abstract}

Keywords: buffalo, mastitis, Staphylococcus, milk, coagulase test

\section{RESUMO}

A mastite é uma inflamação da glândula mamária que afeta o gado leiteiro em todo o mundo, causando perdas econômicas. Staphylococcus coagulase-negativa (SCN) são a causa predominante desse tipo de infeç̧ão. Mostrou-se recentemente que Staphylococcus coagulase-positiva podem ser identificados erroneamente. Assim, o objetivo deste estudo foi caracterizar cepas de Staphylococcus spp. inicialmente classificados como Staphylococcus coagulase-negativa, isolados de búfalas com mastite subclínica. $O$ leite de búfalas com mastite foi coletado, e nove cepas foram identificadas como SCN por testes fenotípicos. Metodologias moleculares identificaram as cepas como Staphylococcus chromogenes coagulase-negativa (5) Staphylococcus hyicus coagulase-positiva (2) e Staphylococcus aureus coagulase-positiva (2). Os resultados reforçam a necessidade de identificar as cepas em termos de espécie, a fim de se evitarem erros de identificação e estar atento à classificação utilizando o teste de coagulase sozinho.

Palavras-chave: búfalo, mastite, Staphylococcus, leite, teste de coagulase

\section{INTRODUCTION}

Mastitis is an inflammation of the mammary gland that has a high impact on dairy cattle worldwide and causes considerable economic losses due to loss of milk quality and quantity, as well as the costs associated to treatment, veterinary services, culling and dairy cow replacement (Fabres-Klein et al., 2014). The disease is classified as moderate or severe, and might be caused by different bacterial species, but mainly Staphyococcus strains (Pyörälä and Taponen, 2009).

Recebido em 10 de agosto de 2016

Aceito em 4 de fevereiro de 2017

* Autor para correspondência (corresponding author)

E-mail: marciagm@micro.ufrj.br 
Coagulase-negative staphylococci (CNS) have been considered pathogens of lesser importance, while Staphylococcus aureus has been considered a more important pathogen due its ability to form biofilm (Lee et al., 2014). However, more recent studies have shown that CNS are emerging pathogens associated with the occurrence of mastitis and persistence of intramammary infection in dairy cattle (Fry et al., 2014).

There has been an increasing interest in buffalo milk, both in research and as investment in various countries, mainly due to its beneficial nutritional content and for the production of cream, butter, yogurt, as well as many types of cheese (Michelizzi et al., 2010). Thus, there is a growing interest to produce high quality buffalo milk and to control diseases that might affect its production, such as mastitis.

Our research group received a total of $42 \mathrm{~S}$. chromogenes isolates, from a 51 collection of Staphylococcus spp strains obtained from milk samples of buffalo with subclinical mastitis and kept in the culture collection at the Embrapa Dairy Cattle Research Center (Juiz de Fora, Minas Gerais, Brazil). These 42 were sent to our laboratory with ambiguous identification since they were initially classified as coagulasepositive staphylococci by the coagulase test (Coagu-Plasma, Laborclin, Pinhais, PR, Brazil) but later identified as $S$. chromogenes, a coagulase-negative staphylococci using the $16 \mathrm{~S}$ rRNA gene (similarity $\geq 99 \%$ ). Coagulasepositive characteristic was not reported before for the species $S$. chromogenes and we were able to describe this novel phenotype of clotting the plasma in this collection of $S$. chromogenes strains (Santos et al., 2016).

The goal of this study was to characterize the remaining 9 isolates previously characterized as coagulase-negative Staphylococcus spp. strains in the collection of isolates from milk of buffaloes with mastitis. We applied molecular investigation to confirm the primary identification based on coagulase tests, evaluated the antimicrobial resistance profile and investigated both the biofilm formation and the presence of the bap and icaA genes which are involved in the synthesis of this structure.

\section{MATERIALS AND METHODS}

Milk samples were collected from five dairy buffalo herds between March and November 2003. The herds were visited six times and milk samples were collected for microbiological examination and somatic cell counts. The herds were composed of water buffaloes of the breeds Murrah, Mediterranean, Jafarabadi and their respective crosses, with different ages and different lactation stages. Animals were raised and kept on pasture and with free access to water ponds to immerse themselves. The buffaloes were hand-milked and the calves were kept close to their mothers during milking in order to stimulate milk ejection. The herds, with 18 to 35 animals (average 27), were kept at four municipalities in the Region of Alto São Francisco, in the State of Minas Gerais. Milk sample collection was performed after washing the teats and disinfecting the tips with $70 \%$ alcohol. The first few streams of milk were discarded and samples were collected into sterilized flasks and frozen. A total of 1,304 milk samples were collected and 1,116 were negative upon microbiological examination by culturing $0.01 \mathrm{ml}$ of each milk sample on $5 \%$ ovine blood agar plates. The plates were incubated for 24-48 hours at $37^{\circ} \mathrm{C}$ and colony morphology was observed. Gram staining and identification tests were performed according to National Mastitis Council (Microbiological..., 2004). Gram- and catalase-positive cocci resistant to $0.04 \mathrm{U}$ of bacitracin were identified as Staphylococcus sp. Coagulase-negative and coagulase-positive staphylococci were identified by the tube coagulase test. CNS were considered as mastitis causing pathogens when present in pure culture of six or more colonies on the ovine blood agar plates. Coagulase-negative and coagulasepositive staphylococci were identified through the tube coagulase test. As cited above, a total of 51 staphylococci isolates were obtained; only the 9 coagulase-negative strains isolates were selected for this study since the 42 classified as coagulase-positive were characterized in a previous study (Santos et al., 2016). Figure 1 shows a list with the identification number attributed to each isolate and the respective herd from which it was collected.

The profile of antimicrobial resistance was evaluated in Muller-Hinton medium by the disk diffusion method against the following 
antimicrobial discs (Cecon, SP, Brazil): ampicillin $(10 \mu \mathrm{g})$, cefoxitin $(30 \mu \mathrm{g})$, clindamycin $(2 \mu \mathrm{g})$, erythromycin $(15 \mu \mathrm{g})$, gentamicin $(10 \mu \mathrm{g})$, oxacillin $(1 \mu \mathrm{g})$, penicillin $\mathrm{G}$ (10 IU), rifampin $(5 \mu \mathrm{g})$, sulfazotrim $(25 \mu \mathrm{g})$ and tetracycline $(30 \mu \mathrm{g})$. Interpretation of the results followed the Clinical and Laboratory Standards Institute protocols (Performance..., 2013a,b). The ATCC strain, S. aureus 25923 was used as control for the disk diffusion test.

The ability of the isolates to produce biofilm was analyzed as described by Ahn, et al (2005) using S. epidermidis ATCC 35984 as positive and $S$. epidermidis ATCC 12228 as negative controls. The experiments were performed in triplicate and classified according to Stepanovic et al., 2007.

The primers used were: mecA MRS1 (5, TAGAAATGACTGAACGTCCG 3') and MRS2 (5, TTGCGATCAATGTTACCGTAG 3') (Santos et al., 1999); icaA Forward (5' CGATGGGCTCAAGGTGG 3') and icaA Reverse (5' TTCTTTTCGTAGCGACTGTC 3') for the gene icaA, and bap2 Forward (5' GAGCCAGATAAACAACAAGAAG 3') and bap2 Reverse (5' CATGCTCAGCAATAATTGGATC 3') (Potter et al., 2009). The expected sizes of mecA, icaA and bap amplifications were approximately 154 , 290 and 600bp, respectively.

To identify the Staphylococcus isolates, three different approaches were performed as follows. Universal primers $9 \mathrm{f}$ (5'GAGTTTGATCCTGGCTCAG 3') and 1492r (5' GGYTACCTTGTTAACGACTT 3') (20 pmol) corresponding to the Escherichia coli rrs gene (Weisburg et al.,1991), were used to amplify the 16S rRNA gene and to sequence both strands. Sequences were identified in the GenBank database by the Blast search tool, available at www.ncbi.nlm.nihgov/BLAST. Polymerase Chain Reaction - Restriction Fragment Length Polymorphism (PCR-RFLP) was performed using a protocol proposed by our group to identify Staphylococcus spp. using the endonuclease AluI to analyze the restriction fragment length polymorphism of an amplified fragment of the groEL gene using the degenerate primers H279A (5' GAIIIIGCIGGIGA(TC)GGIACIACIAC 3') and $\mathrm{H} 280 \mathrm{~A}$ (TC)(TG)I(TC)(TG)ITCICC(AG)AAICCIGGIG
C(TC)TT 3') were applied. The identification of the species-specific restriction fragment profiles was based on the results published by Barros et al. (2007) and Santos et al. (2008). Sodium Dodecyl Sulfate-Polyacrylamide Gel Electrophoresis (SDS-PAGE) was applied to analyze extracts of whole-cell proteins corresponding to $10^{7} \mathrm{CFU}$ from overnight cultures of the strains were evaluated by SDSPAGE as previously described (Laport et al., 2001).

The analysis of genetic diversity by electrophoresis on Pulsed-Field Gel Electrophoresis (PFGE) was performed according to the protocol described by Nunes et al. (2005). The strains genomic fragment patterns were analyzed by comparison, using the BioNumerics program, version 6.0 and classified according to the criteria of Van Belkun et al. (2007).

\section{RESULTS AND DISCUSSION}

Sequencing of the rrs identified the nine isolates as S. aureus, Staphylococcus hyicus and Staphylococcus chromogenes. Sequence homology found for the strains ranged between 98 and $100 \%$. These nine isolates had been previously classified as coagulase-negative Staphylococcus spp. by the coagulase test. However, rrs sequencing identified five isolates as $S$. chromogenes, a coagulase-negative species, and two isolates as $S$. hyicus which belongs to the coagulase variable group. However, to our surprise, these last two isolates were identified as $S$. aureus, the major coagulase-positive group. Identification of coagulase-positive isolates among a group previously identified as belonging to CNS indicates that the coagulase test could lead to misidentification. Coagulasenegative $S$. aureus variants have already been described and it has been alerted that incorrect diagnosis could result from bovine mastitis milk isolates (Akineden et al., 2011). These results show the importance of identifying the CNS strains to the species level in order to avoid misidentification. Since the rrs gene has been questioned as a suitable discriminatory target gene to identify Staphylococcus species (Ghebremedhin et al., 2008), we decided to apply a PCR-RFLP protocol used by our group to identify Staphylococcus spp. The S. aureus and $S$. hyicus strains presented a restriction profile 
compatible with these species. However, when the five strains previously identified as $S$. chromogenes by rrs gene sequencing were analyzed, only two isolates (5411 and 5580) were confirmed, whereas three isolates (5369, 5410 and 5424) presented a previously unknown RFLP-PCR restriction profile. Due to the inability to identify these three $S$. chromogenes strains by RFLP-PCR, we decided to apply a third molecular technique that analyzes total cellular proteins. In the SDS-PAGE, these three S. chromogenes strains (5369, 5410, and 5424) presented a pattern of bands similar to $S$. chromogenes 610 (Santos et al., 2008), thus, confirming the identification previously obtained by rrs sequencing.

In bovine mastitis, antimicrobials are administered for treatment of clinical cases and, as a preventive measure, in the dry cow therapy. Although this use has not been related to the emergence of resistance among mastitis pathogens, the use of antimicrobials in dairy cows has been shown to contribute to increased antimicrobial resistance (Saini et al., 2012). Among the nine strains studied, seven were susceptible to all antimicrobials tested. Only the two $S$. aureus strains were resistant to penicillin and ampicillin. Additionally, they were also resistant to erythromycin at intermediate levels. No mecA gene was detected in any of the isolates. The five $S$. chromogenes and the two $S$. hyicus isolates were susceptible to all antimicrobials tested. Conversely, varying levels of antimicrobial resistance, from high to low, were described in cases of buffalo mastitis in northeastern Brazil (Medeiros et al., 2011). Although, antimicrobial drugs were rarely used in the targeted buffalo herd, the authors suggested that the resistance found was related to the fact that these buffaloes were raised close to cattle, where the use of antimicrobial drugs was significantly higher (Medeiros et al., 2011). In our work, only buffaloes were raised at the five farms analyzed and these animals were not treated with antimicrobials. This could be a reason for the low antimicrobial resistance observed in these strains. Additionally, only the S. aureus isolates were resistant to penicillin, ampicillin, and intermediate levels of erythromycin. This finding is not surprising as these antimicrobials are commonly used to treat mastitis (Pyörälä et al., 2014) and thus may contribute for the selection of these resistant strains. Even though, in this work, the mecA gene was not detected in any of the strains, using the protocol of Santos et al., (1999); methicillinresistant staphylococci have already been reported as bovine mastitis agents (Seixas et al., 2014) and attention should be paid to monitor the presence of this antimicrobial resistance gene.

The production of biofilm can reduce the inflammatory response in infected animals, reducing production of somatic cells and thus keeping the mastitis at a milder level (Cucarella et al., 2004). Keeping this in mind, the ability of the isolates to produce biofilm was investigated and four strains were classified as moderate-, two as weak- and three as non-producers of biofilm, according to Stepanovic et al., 2007. No strong producer strain was detected in this analysis (Figure 1). Both S. aureus strains, isolated from the milk of buffaloes presenting subclinical mastitis, were classified as moderate biofilm producers. This is in agreement with the possibility that these pathogenic strains were the real agents of the sub-clinical mastitis detected. The icaA gene was only detected in the S. aureus strain that was a moderate biofilm producer. The bap gene was found in all five $S$. chromogenes strains, including the weak and non-biofilm producers, and in one $S$. aureus strain (isolate 5422). Neither icaA nor bap genes were detected in the $S$. hyicus strains (Figure 1). According to Vasudevan et al., (2003), the ica gene has a high prevalence among $S$. aureus isolated from mastitis cases, including the strains that are unable to form biofilm in vitro. The two $S$. aureus strains characterized in this work were classified as moderate-producers and showed amplification for icaA. In contrast, the $S$. hyicus 5580 and S. chromogenes 5369 strains were classified as moderate biofilm producers but showed no amplification of icaA. It is possible that these strains have an icaA-independent mechanism of biofilm production. This mechanism has been previously reported by Toledo-Arana et al., (2005) who showed that $S$. aureus strains were able to produce biofilm in the absence of the poly-N-acetylglucosamine (PNAG) exopolysaccharide when the icaADBC operon was removed. Most strains of $S$. chromogenes were classified as non-producers or weak producers of biofilm, and the detection of the bap gene indicates that the presence of this gene alone does not determine biofilm production. Phase-variation could be involved in 
the expression of bap in S. aureus (Tormo et al., 2007). It has been demonstrated that biofilm producer strains $\left(\mathrm{bap}^{+}\right)$could present biofilmnegative colonies with no transcription of the bap gene (Tormo et al., 2007; Vasudevan et al., 2003). Therefore, we cannot discard the hypothesis that the bap gene was not transcribed in at least some of the non-biofilm producer and bap positive isolates analyzed in this work.

Analysis of the genetic diversity among strains by PFGE provides a better understanding of the distribution of the strains, which may help to trace the origin of the strains causing mastitis and, thus, may shed light on how these strains are being transmitted between animals. The fragment patterns of genomic DNA strains obtained by PFGE were analyzed by comparison using the BioNumerics program, version 6.0 and classified according to the criteria of Van Belkum et al., (2007). Figures 1A to $1 \mathrm{C}$ show the dendrogram found for $S$. aureus, S. chromogenes and $S$. hyicus, respectively. Among the two $S$. aureus isolates, more than $80 \%$ of similarity was observed, thus identifying them as belonging to the same clonal group. However, a polyclonal distribution was observed among the $S$. chromogenes and S. hyicus isolates. A unique pulsotype for the $S$. aureus strains suggests that a transmission could have occurred among animals from different herds. Conversely, a lesser genetic relationship was detected among the isolates of $S$. chromogenes and S. hyicus, indicating that probably no transmission occurred among animals, not even among those belonging to the same herd.

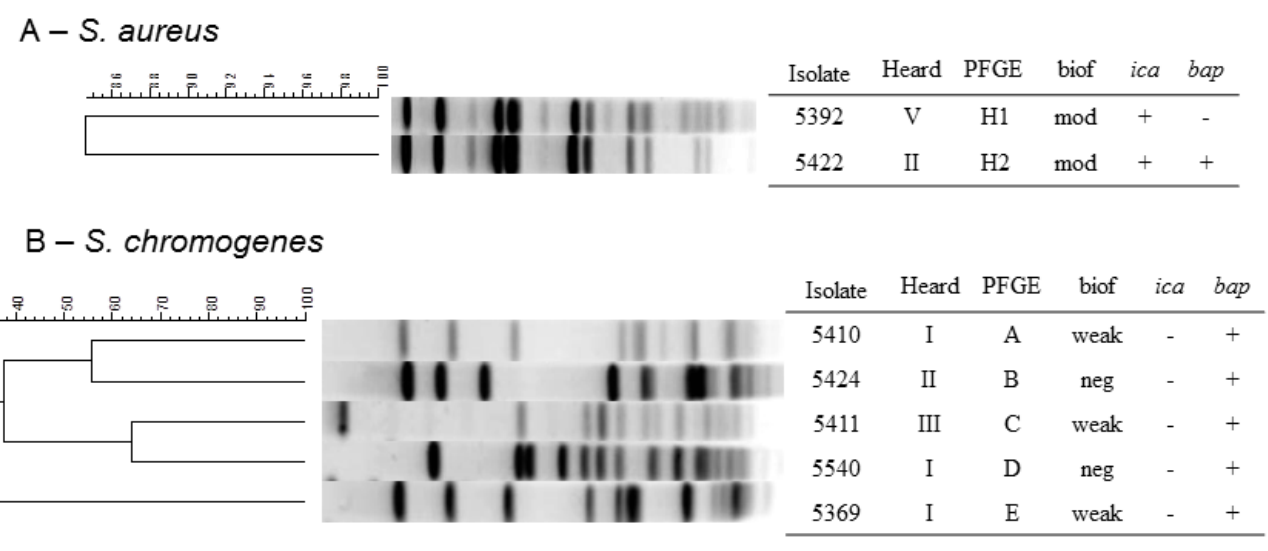

C - S. hyicus

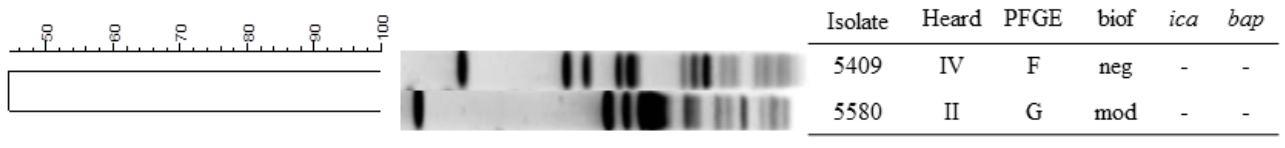

Figure 1. Dendrogram of pulsed-field gel electrophoresis (PFGE) profiles of AluI restriction enzymedigested genomic DNA of A) Staphylococcus aureus, B) Staphylococcus chromogenes and C) Staphylococcus hyicus isolates and their classification according the PFGE profile (A-H), herd (I, II ,III, IV, or V), capacity of biofilm formation (biof): weak, moderate (mod) or negative (neg), and presence $(+)$ or absence (-) of icaA and bap genes.

In conclusion, most veterinary laboratories are only able to differentiate isolates into coagulasepositive or coagulase-negative Staphylococcus spp. depending on results of tube coagulase test. In this work, and in a recently publish by our group (Santos et al., 2016), we gave evidence of the higher accuracy of molecular tests over phenotypic assays. We support the need to identify the isolates at species level in order to avoid misidentification and to be cautious of the classification using the coagulase test alone. We observed that the coagulase test could lead to misidentification and that sequencing of the $16 \mathrm{~S}$ rRNA codifying gene ( $r r s$ ) proved to be a 
reliable approach to identify isolates from buffalo milk. We suggest that the use of molecular and phenotypical analyses to reveal the identity and transmissibility of bacterial species causing mastitis in buffalo could help to develop preventive measures or offer treatment options for infected animals. Our results strongly support the need to identify the isolates at species level in order to avoid misidentification and to be cautious of the classification using the coagulase test alone.

\section{ACKNOWLEDGEMENTS}

We thank Orlando dos Santos, in memoriam, for his technical assistance. This study was supported by Brazilian grants, Fundação Amparo à Pesquisa do Estado do Rio de Janeiro (FAPERJ-grant E26/112.649/2012), Conselho Nacional de Desenvolvimento Científico e Tecnológico (CNPqgrant 476119/2012-0), and Coordenação de Aperfeiçoamento Pessoal de Nível Superior (CAPES/Proex-grant 23038.001255/2011-29).

\section{REFERENCES}

AHN, S.J.; LEMOS, J.A.; BURNE, R.A. Role of HtrA in growth and competence of Streptococcus mutans UA159. J. Bacteriol., v.187, p.30283038, 2005.

AKINEDEN, O.; HASSAN, A.A.; SCHNEIDER, E.; USLEBER, E.J. A coagulase-negative variant of Staphylococcus aureus from bovine mastitis milk. J. Dairy. Res., v.78, p.38-42, 2011.

BARROS, E.M.; IÓRIO, N.L.P.; BASTOS, M.C.F.; SANTOS, K.R.N. et al. Species-level identification of clinical staphylococcal isolates based on polymerase chain reaction- restriction fragment length polymorphism analysis of a partial groEL gene sequence. Diagn. Microbiol. Infect. Dis., v.59, p.251-257, 2007.

CUCARELLA, C.; TORMO, M.A.; UBEDA, C.; TROTONDA, M.P. et al. Role of biofilmassociated protein bap in the pathogenesis of bovine Staphylococcus aureus. Infect. Immun., v.72, p.2177-2185, 2004.

FABRES-KLEIN, M.H.; AGUILAR, A.P.; SILVA, M.P. et al. Moving towards the immunodiagnosis of staphylococcal intramammary infections. Eur. J. Clin. Microbiol. Infect. Dis., v.33, p.20952104, 2014
FRY, P.R.; MIDDLETON, J.R.; DUFOUR, S.; PERRY, J. et al. Association of coagulasenegative staphylococcal species, mammary quarter milk somatic cell count, and persistence of intramammary infection in dairy cattle. $J$. Dairy Sci., v.97, p.4876-4885, 2014.

GHEBREMEDHIN, B.; LAYER, F.; KÖNIG, W.; KÖNIG B. Genetic classification and distinguishing of Staphylococcus species based on different partial gap, 16S rRNA, hsp60, rpoB, sodA, and tuf gene sequences. J. Clin. Microbiol., v.46, p.1019-1025, 2008.

LAPORT, M.S.; CASTRO, A.C.D.; VILLARDO, A.; LEMOS, J.A.C. et al. Expression of the major heat shock proteins DnaK and GroEL in Streptococcus pyogenes: a comparison to Enterococcus faecalis and Staphylococcus aureus. Curr. Microbiol., v.42, p.264-268, 2001.

LEE, S.H.; MANGOLIN, B.L.C.; GONÇALVES, J.L.; NEEFF, D.V. et al. Biofilm-producing ability of Staphylococcus aureus isolates from Brazilian dairy farms. $J$. Dairy Sci., v.97, p.1812-1816, 2014.

MEDEIROS, E.S.; FRANÇA, C.A.; KREWER, C.C.; PEIXOTO, R.M. et al. Antimicrobial resistance of Staphylococcus spp. isolates from cases of mastitis in buffalo in Brazil. J. Vet. Diagn. Invest., v.23, p.793-796, 2011.

MICHELIZZI, V.N.; DODSON, M.V.; PAN, Z.; AMARAL, M.E.J. et al. Water buffalo genome science comes of age. Int. J. Biol. Sci., v.6, p.333-349, 2010.

MICROBIOLOGICAL procedures for the diagnosis of bovine udder infection and determination of milk quality. 4.ed. Verona: National Mastitis Council, 2004.

NUNES, A.P.; TEIXEIRA, L.M.; BASTOS, C.C.; SILVA, M.G. et al. Genomic characterization of oxacillin-resistant Staphylococcus epidermidis and Staphylococcus haemolyticus isolated from Brazilian Medical Centers. J. Hosp. Infect., v.59, p.19-26, 2005.

PERFORMANCE standards for antimicrobial disk and dilution susceptibility tests for bacteria isolated from animals. Document VET01-A4. Approved standard. 4.ed. Wayne, PA: CLSI, 2013a. 
PERFORMANCE standards for antimicrobial disk and dilution susceptibility tests for bacteria isolated from animals. Second Informational Supplement. CLSI document VET01-S2. Wayne, PA: CLSI, 2013b.

POTTER, A.; CEOTTO, H.; GIAMBIAGIDEMARVAL, M.; SANTOS, K.R.N. et al. The gene bap, involved in biofilm production, is present in Staphylococcus spp. strain from nosocomial infections. J. Microbiol., v.47, p.319326, 2009.

PYÖRÄLÄ， S.; TAPONEN S. Coagulasenegative staphylococci - emerging mastitis pathogens. Vet. Microbiol., v.134, p.3-8, 2009.

PYÖRÄLÄ, S.; TAPONEN, J.; KATILA, T. Use of antimicrobials in the treatment of reproductive diseases in cattle and horses. Reprod. Domest. Anim., v.49, p.16-26, 2014.

SAINI, V.; MCCLURE, J.T.; SCHOLL, D.T.; DEVRIES, T.J. et al. Herd-level association between antimicrobial use and antimicrobial resistance in bovine mastitis Staphylococcus aureus isolates on Canadian dairy farms. $J$. Dairy Sci., v.95, p.1921-1929, 2012.

SANTOS, D.C.; LANGE, C.C.; AVELLARCOSTA, P.; SANTOS, K.R.N. et al. Staphylococcus chromogenes: a coagulasenegative Staphylococcus that can clot plasma. $J$. Clin. Microbiol., v.54, p.1372-1375, 2016.

SANTOS, K.R.; TEIXEIRA, L.M.; FONSECA, L.S.; GONTIJO FILHO, P.P. DNA typing of methicillin-resistant Staphylococcus aureus isolates and factors associated with their nosocomial acquisition at two Brazilian university affiliated hospitals. J. Med. Microbiol., v.48, p.17-23, 1999.

SANTOS, O.C.S.; BARROS, E.M.; BRITO, M.A.V.P.; BASTOS, M.C.F. et al. Identification of coagulase-negative staphylococci from bovine mastitis using PCR-RFLP of the groEL gene. Vet. Microbiol., v.130, p.134-140, 2008.
SEIXAS, R.; SANTOS, J.P.; BEXIGA, R.; VILELA, C.L. et al. Antimicrobial resistance and virulence characterization of methicillinresistant staphylococci isolates from bovine mastitis cases in Portugal. J. Dairy Sci., v.97, p.340-344, 2014.

STEPANOVIC, S.; VUKOVIC, D.; HOLA, V.; BONAVENTURA, G. et al. Quantification of biofilm in microtiter plates: overview of testing conditions and practical recommendations for assessment of biofilm production by staphylococci. Acta Pathol. Microbiol. Immunol. Scand., v.115, p.891-899, 2007.

TOLEDO-ARANA A.; MERINO, N.; VERGARA-IRIGARAY, M.; DÉBARBOUILLÉ, M. et al. Staphylococcus aureus develops an alternative, ica-independent biofilm in the absence of the arlRS twocomponent system. J. Bacteriol., v.187, p.53185329, 2005.

TORMO M.A.; UBEDA, C.; MARTÍ, M.; MAIQUES, E. et al. Phase-variable expression of the biofilm-associated protein (Bap) in Staphylococcus aureus. Microbiology, v.153, p.1702-1710, 2007.

VAN BELKUN, A.; TASSIOS, P.T.; DIJKSHOORN, L.; HAEGGMAN, S. et al. European Society of Clinical Microbiology and Infectious Diseases (Escmid) Study Group on Epidemiological Markers (Esgem). Guidelines for the validation and application of typing methods for use in bacterial epidemiology. Clin. Microbiol. Infect., v.13, Suppl.3, p.1-46, 2007.

VASUDEVAN, P.; NAIR, M.K.; ANNAMALAI, T.; VENKITANARAYANAN, K.S. Phenotypic and genotypic characterization of bovine mastitis isolates of Staphylococcus aureus for biofilm formation. Vet. Microbiol., v.92, p.179-85. 2003.

WEISBURG, W.G.; BARNS, S.M.; PELLETIER, D.A.; LANE D.J. 16S ribosomal DNA amplification for phylogenetic study. $J$. Bacteriol., v.173, p.697-703, 1991. 